\title{
Consuming the image of "Japan" in British Art Deco fashion
}

\author{
Hiroka Goto / Tsuda College / Tokyo / Japan
}

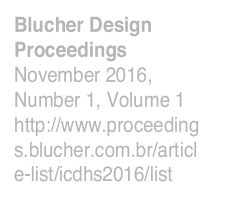

\begin{abstract}
Art Deco is a decorative arts style that originated in the mid-1910s, developed over the 1920 s and 1930s, and is particularly closely related with 1920s France. Some of the inspirational sources for Art Deco were the visual cultures of various exotic regions, such as East Asia. In particular, Chinese and Japanese styles were two of the most important influences on the eclectic mix of styles and spirit of Art Deco. In this paper, we discuss how Japanese styles were established and consumed in British Art Deco fashion. Although Japonisme goods were already popular in the nineteenth century, their decorative and picturesque motifs became practical fashion items during the Art Deco period.
\end{abstract}

\section{Keywords}

Art Deco fashion, British consumer culture, Japonisme, Oriental design, silk

\section{Introduction}

Art Deco design was eclectic; it reflected exotic inspirations and became a modern and unique transnational design style. Traditional methods and techniques from East Asia were a significant influence on Art Deco's new exotic style. Design historian Gillian Naylor (2003) noted that British industrial art was conservative and indifferent to foreign art movements. In the early 1920s, British design critics 'had inherited the Arts and Crafts conscience - the moralities of practical use and fitness for purpose that had made their predecessors'. In addition, textile design was important in the British Art Deco context, and their 'vibrant colours, emphatic repeats, florals and abstracts signalled the passing of William Morris's influence' (Naylor, 2003, p. 232).

This study analyses 1920s British consumer culture, which was a significant period for Oriental influences on design, especially Japanese design. The 1920s were also an important period for the silk trade between Japan and Britain. This study researched 1920s fashion magazines, such as Vogue and The Queen, and business magazines such as Drapers Record, and discusses how and why some Japanese goods-e.g., kimonos and umbrellas - appeared frequently in the British fashion media. Although Japonisme goods were already popular in the late nineteenth century, their decorative and picturesque motifs became practical fashion items during the Art Deco period. By 'practical', I mean that these goods were widely used daily by not only artists, but also by ordinary people. Kimono design was partially introduced into Western garment designs and Japanese umbrellas were used as sunshades.

Arguably, the key to this change was the material used. Japanese silk fabrics or silk embroideries were often displayed in 1920s British magazines and advertisements. Silk prices were considerably reduced in the twentieth century because of massive silk production in Japan, which made silk comparatively more accessible after being treated as a luxury for a long time. This availability encouraged Japonisme fashions among British women, especially upper-middle class women, as shown by the readership of the magazines researched for this study. This transnational phenomenon was most clearly illustrated by the British adoption of kimono style and Japanese umbrellas.

\section{Japanese Silk in Britain}

Since the sixteenth century, England depended on raw silk imports from France and Italy because the British climate was unsuitable for sericulture. However, the British silk industry continued to develop, especially in the early nine- 
teenth century. Britain was one of the four largest Western markets for silk and the world consumption of raw silk increased 5.5 times from 1875-1877 to 1927-1929 (Federico, 2009, p. 43). The British silk industry differed from all other European silk industries because it was not an export industry and it could not even satisfy the large domestic market demand, which continued even after the First World War. Within 10 years after the First World War, when raw silk processing business was at its zenith from 1924 to 1928, Britain had imported one million pounds of raw silk (Flugge, 1943, p. 95).

Many Japonisme fashion goods were made from silk. Silk originated in China and were exported to Europe around the twelfth century. In 1873, China boasted about being the main raw silk exporter, but Japanese raw silk exports had overtaken Chinese silk exports by 1905 . In 1930 , Japanese silk comprised $80 \%$ of the global silk trade (Li, 1982, pp. 192-198). The massive volume of Japanese silk produced was mainly exported to Europe and America. By the 1920s, silk had become the main material representing Japanese culture.

Great attention was paid to Japanese silk during two international occasions. In 1910, the Japan-British Exhibition was held at White City in London, which celebrated and reinforced the Anglo-Japanese Alliance of 1902. The Exhibition was strongly supported by the Japanese Foreign Minister Jutaro Komura. Silk products were introduced as 'one of the most important products of Japan' (Matsumura, 2011, p. 213). A large variety of silks and silk fabrics were exhibited in the textile industry department of the Exhibition, which were reported as follows:

In other classes of silk fabrics, such as crêpe for umbrellas... A large number of kimonos adapted to Western requirements took the fancy of many people, so much so that their influence became noticeable on ladies' costumes in this country (Matsumura, 2011, p. 213).

Kimonos and umbrellas using Japanese silk fabrics were exhibited and generated great demand for these products in Britain. Not only Japanese silk products, but also sericulture methods and the history of silk in Japan were introduced in the textile section of the Exhibition. Thus, this exhibition laid the foundation for the popularity of Japanese silk in the twentieth century, which continued into the Art Deco period of the 1920s.

The second international occasion was the Exposition Internationale des Arts Décoratifs et Industriels Modernes held in Paris in 1925. Japan made another great impact by focusing on exhibiting kimonos and Japanese umbrellas, such as the Yuzen kimono by Takashimaya Gofukuten (kimono shop), the Hikida 'so-sibori' (overall tie-dyeing), and nagajuban (a long undergarment) made by Urata Seizo. Other kimonos won the gold, silver, and bronze prizes. Furthermore, many Japanese umbrellas and parasols made of paper and silk were exhibited. The parasol made by Teshigawara Limited Partnership Company won the only grand prize among the Japanese exhibits in the exposition (Shokoshomukyoku, 1927, p. 114). Japan considered the Western market when planning its exhibitions.

\section{Ornamentalism in fashion}

\section{Kimono}

The use of kimonos in the nineteenth century can be classified roughly into two categories. Initially, kimonos were used as picturesque motifs and often appeared in works by European painters like Dante Gabriel Rossetti and James McNeill Whistler from the middle of the 1860s. Kimonos were then worn as a dressing gown.

In the twentieth century, European fashion shifted in its use of kimonos. In Art Deco fashion, especially in the 1920s, kimonos were popular and continued to be worn informally as dressing gowns, as they were in the nineteenth century. However, there were obvious differences between the kimono fashions in the nineteenth and twentieth centuries.

Western garment designs directly adopting the kimono shape appeared in the early twentieth century and some representative examples were 'kimono coat', 'kimono sleeve' and 'obi belt' designs. Especially in British women's magazines in the early 1920s, clothes using 'kimono sleeve' and 'kimono shoulder line' designs were frequently observed. In 1928, British Vogue introduced an evening wrap that was sold as a Vogue pattern with the caption, 'The sleeves are kimono in front' (Vogue, Oct 3, p. 96) (Figure 1). The straight kimono lines coincided with the vogue of Art Deco fashion. Western design also adopted the shape of a kimono in the 'kimono coat' often seen in the early twentieth century, which was first produced in the early 1900s by the French couturier, Paul Poiret. British fashion houses, such as Burberry and Redfern, also sold kimono coats in the 1920s. 


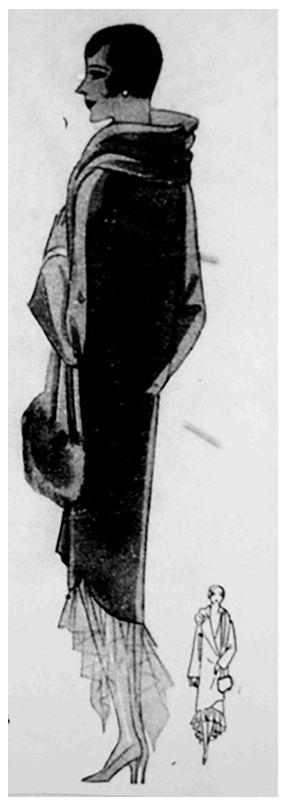

Fig. 1: Evening Wrap (Vogue (UK), 3 October 1928, p. 96. (c) Bunka Gakuen University Library)
European fashion design inspired by kimono elements followed not only the shape of sleeves, but also the use of ribbons. In 1923, a feature article 'Spring Movements in the Paris Fashion Market' published in Drapers Record stated that 'Indian and Persian designs in novel effects and colour combinations on silk crêpe and very wide ribbons (the latter for hats or the new "Obi" bows on evening frocks) are expected to be much demand later on' (Drapers Record, 13 January 1923, p. 79). Some designs from Eastern countries were confused and lumped together. However, a kimono element, 'obi', was seen as a remarkable new design and was used as a ribbon decoration on frocks. A similar description of obi ribbons was also published in a Drapers Record article, 'Fashion Notes from Paris', from the same year, which described a trend in evening dresses as 'even when draped, the bows are placed on the hips, Japanese fashion' (Drapers Record, 17 February 1923, p. 431).

Japonisme clothing frequently incorporated Japan-inspired motifs in prints and patterns. Western designers produced several clothing items with Japan-inspired motifs and designs. In addition, motifs were designed by a Japanese designer, Léonard Foujita, who was active as a painter and printmaker in 1920s Paris. A Western-style dress printed with a Japanese pattern was published in Drapers Record with the caption 'Maid's Gown Printed Artificial Silk Ninon, pretty Japanese effect' (Drapers Record, 20 April 1929, supplement ii) (Figure 2). Flowers and temple architecture can be seen in the pattern, and the woman modelling the gown is also holding a Japanese parasol. Animal and floral motifs from Japonisme designs have been adopted in artworks, arts and crafts, and interior products since the Art Nouveau period in the nineteenth century. Similarly, these Japanese motifs were also incorporated into Art Deco fashion. The preferred motifs appear to have been taken from nature.

The use of kimono as informal wear, such as dressing or tea gowns, did not fade away and it continued to be popular in Britain from the late nineteenth century to the early twentieth century. Accordingly, kimono designs in Art Deco fashion were used not only for informal wear since the nineteenth century, but also in Western garments, such as kimono sleeves and coats, and dresses embroidered with Japan-inspired motifs.

Why did Art Deco fashion incorporate kimono elements? David Cannadine (2002, p. xix) noted that the British Empire was "concerned with what has recently been called the "construction of affinities" on the presumption that society on the periphery was the same as, or even occasions superior to, society in the metropolis'. This observation was demonstrated by the consumer culture for kimonos in Britain. British designers combined kimono and Western garment designs, which were worn by British consumers, especially women who wore kimonobased designs in Western clothing, such as coats. British consumers also similarly utilized Japanese umbrellas.

\section{Japanese Umbrellas}

Another Japan-inspired object represented prominently in Art Deco fashion is the Japanese umbrella. In the nineteenth century, Japanese umbrellas as well as kimono designs were used as picturesque motifs.

The practice of walking under an umbrella in the rain did not begin to take hold in Britain until about the late eighteenth century. Professional middle-class citizens, such as doctors, began to use umbrellas for practical reasons related to their occupation. In the mid-nineteenth century, light and slim umbrellas appeared; gentlemen then began to substitute an umbrella for a walking stick.

In contrast to an umbrella representing the carriage-owning class, the parasol was a status symbol for the upper and upper-middle classes who frequently rode in a carriage. Accordingly, a large-sized parasol with a long handle came to be popular after the 1860s. In almost the same period when these parasols were in fashion, Japanese arts and crafts were increasingly attracting British attention, including at the London International Exhibition on Industry and Art held in South Kensington in 1862. From the late 1870s to the 1880s, and in the 1920s, Japanese parasols became popular in Europe and were mostly used at the beach (Ito, 1996, p. 253).

Japanese umbrellas appeared in British magazines in the mid-1910s. In 1915, Colour Magazine included a fashion plate of a woman holding a Japanese umbrella on the seaside (Colour Magazine, June 1915, p. 189). In the twentieth century, Japanese umbrellas were used as a practical and fashionable tool for keeping dry or 
blocking the sun, which is quite different from the way they were used in the nineteenth century. Photographs of British celebrities published in The Queen frequently showed Japanese umbrellas being used as sunshades in

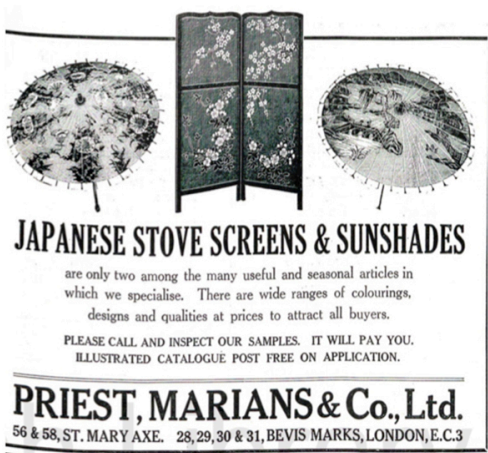

Fig. 3: Priest, Marians \& Co., Ltd. Advertisement (Drapers Record, 12 April 1924, p. 65) places for social interaction.

In addition to the change in use between the end of the nineteenth century and the twentieth century was the diversification of materials used to make Japanese umbrellas. Before the 1920s, Japanese umbrellas were mainly made from oil-paper or silk with embroidery. The latter style was frequently seen in 1920s magazines.

As shown in British women's magazines published in the 1920s, all Japanese umbrellas made of paper, silk, or cotton were used as a sunshade to protect people from the sun: 'This year one sees a great many Japanese parasols. A number have really come from Japan, and are made of oiled paper, transparent round the edge; others are of silk, either plain or decorated with Japanese embroidery' (The Queen, 7 August 1920 p. 161). The Queen went on to explain that 'Japanese sunshades are the great fantasy of the summer, and are varied and elegant; the one seen here is of shot black and silver, the transparent border being of black crêpe georgette; it is simply mounted on bamboo' (The Queen, 7 August 1920, p. 161). Crêpe georgette is a thin silk cloth; therefore, traditional Japanese umbrellas made from oil-paper, and those made from silk, had become fashionable in Britain during the 1920s.

However, some umbrellas with different designs to Japanese umbrellas were introduced to British consumers as being Japanese umbrellas. For example, The Queen (13 March 1920, p. 378) published a description of parasols as 'Japanese in shape, [they] are of brocaded silk in the same colour and material as the robe they accompany, the handles are in the same style', which differs significantly from original Japanese umbrellas, especially in their shape and use of ribbons. This magazine also described an umbrella as a 'Japanese sunshade of cream voile de soie edged with a fringe and trimmed with blue and grey goffered ribbons' (The Queen, 29 May 1929, p. 695). However, these umbrellas do not look like traditional Japanese umbrellas because they never included a ribbon trim or decorated fringes. These examples may be British-made Japanese parasol designs. Round-shaped umbrellas were probably recognized as being Western designs, and flat-shaped umbrellas were known as Japanese designs.

Some magazine advertisements included information on Japanese parasols. Faudels sold Japanese parasols made of cotton with silk embroidery through its advertisement in Drapers Record (10 March 1923, supplement I). In 1924, Drapers Record published an advertisement for Priest, Marians \& Co., Ltd., which was a photograph of two Japanese parasols and a room divider (12 April 1924, p. 65) (Figure 3). This company was a supplier of Japanese umbrellas; however, the patterns on the umbrellas shown in Figure 3 are gaudy, thus, these umbrellas appear to have been made in Japan with the intention to export them overseas. Japanese parasols for international sale were usually exported to Britain using similar trading companies.

In the British history of umbrellas, the handle was important because it showed status and fashionableness. Umbrellas with similar handles to Japanese handles appeared in the early twentieth century. Liberty introduced umbrellas with 'Japanese Aryma' glass handles (Liberty's Catalogues, 1985, microfilm 1923). In 1920, The Queen published an article about an umbrella with a Japanese ivory handle (The Queen, 7 August 1920, p. 161). In the 1920s, the vogue among upper-middle class women in Britain for Japanese umbrellas, especially those made of silk, had a similar relationship to the use of an umbrella as a status symbol in British history. As for kimonos, Japanese umbrellas were also accepted as being linked with class status in British culture.

Cannadine (2002, p. 122) noted that 'the British created their imperial society, bound it together, comprehended it and imagined it from the middle of the nineteenth century to the middle of the twentieth century in an essentially ornamental mode. For ornamentalism was hierarchy made visible, immanent and actual.' Umbrellas and parasols were historically upper and upper-middle class status symbols in Britain. Therefore, in the 1920s, Japanese silk umbrellas were consumed as a status object reflecting the owner's place in the class hierarchy.

\section{Conclusion}

Kimonos and Japanese umbrellas were linked with the British upper-middle class in the British cultural and historical context because they were made from silk and they were consumed accordingly, especially in British Art Deco fashion. Drapers used Japanese silk ornamentally for the upper-middle classes to represent symbolically their status 
in British hierarchical society.

British Art Deco fashion incorporated Japanese influences into the pre-existing Western clothing designs, such as dressing gowns and coats. Kimonos were used as an ornamental construct. This situation was similar to the formation of the British imperial society constructing affinities.

The development of the Japanese silk industry led to the popularization of silk, which supported the spread of Japonisme goods in British consumer culture. The use of Japanese kimono and umbrella designs were deeply intertwined with the British fashion of the 1920s, and their influence continues to the present day. These Japonisme goods were given meaning in the fashion and class hierarchy of the 1920s by British drapers and consumers because they incorporated silk and were consumed mainly among the upper-middle class.

What happened after the 1920s? In the 1930s, Japanese silk goods were boycotted. Therefore, the popularity of Japonisme goods is assumed to have declined gradually in the 1930s because consuming silk products became a political act, which reduced the demand for Japonisme products in British fashion.

\section{References}

Colour magazine (1915).

Cannadine, D. (2002) Ornamentalism: How the British saw their empire, London: Penguin Books.

Drapers Record (1923) 13 January.

Drapers Record (1923) 17 February.

Drapers Record (1923) 10 March.

Drapers Record (1924) 12 April.

Drapers Record (1929) 20 April.

Federico, G. (2009) An economic history of the silk industry, 1830-1930, Cambridge: Cambridge University Press.

Flugge, E. (1943) Kiito, Tokyo: Kuritashoten,

Ito, N., Asano, T. and Kenya, E. (1996). Journal des dames et des modes 1912-14. Tokyo: Iwasakibijyutsusha.

Li, L. M. (1982) 'Silks by sea: Trade, technology, and enterprise in China and Japan', The Business History Review, vol. 56, no. 2, pp. 192-217.

Liberty's Catalogues 1881-1949: Fashion, design, furnishings (1985), Bath: Mindata Limited.

Naylor, G. (2003) 'Conscience and consumption: Art Deco in Britain', in Benton, C. (ed). Art Deco 19101939, London: V\&A Publications.

Shokoshomukyoku (1927) 1925 Paris Bankokusoushokubijyutsuhakurankai Seihu Sandou Jimuhokokusho [The government's report of the international exposition of modern industrial and decorative arts in 1925 Paris], Tokyo: Shokoshomukyoku.

Matsumura, M. (ed.) (2011) The Japan-British exhibition of 1910: A collection of official guidebooks and miscellaneous publications, vol. 3, Tokyo: Eureka Press.

The Queen (1920) 13 March.

The Queen (1920) 7 August.

The Queen (1929) 29 May.

Vogue (UK) (1928) 3 October.

\section{Biographical note}

Hiroka Goto is a Ph.D. student in the English Language and Literature Department at Tsuda College. Her research interest focus on Japonisme in British consumer culture and design in particular. 